\title{
Ecology and abundance of zooplankton in Karanja reservoir
}

\author{
Shashikanth Majagi $\cdot$ K. Vijaykumar
}

Received: 18 September 2007 / Accepted: 9 April 2008 / Published online: 2 August 2008

(C) The Author(s) 2008

\begin{abstract}
The present work aims to study the Zooplankton seasonal distribution and diversity in Karanja reservoir, Bidar district for the period of two years from October 2001 to September 2003. We have recorded 36 species of which, 15 species belongs to rotifera, 11 species belongs to cladocera, nine species belongs to copepoda and ostracoda three species. Among zooplankton, particularly rotifera was the dominant group throughout the study period and highest count was recorded in the month of March 2003. Cluster analysis was also revealed by dendrogram and Shannon diversity index is also presented. Zooplankton community is also correlated with physicochemical parameters.
\end{abstract}

Keywords Zooplankton - Diversity · Bidar district . Karanja reservoir $\cdot$ Rotifera $\cdot$ Cladocera

\section{Introduction}

The distribution of aquatic organisms, and particularly plankton, has long been known to be heterogeneous. Spatial heterogenisity is common feature in all ecosystems and is the result of many interacting physical and

K. Vijaykumar

Department of Zoology, Gulbarga University,

Gulbarga, Karnataka, India

e-mail: katepaga_vijaykumar@yahoomail.com

\section{S. Majagi $(\bowtie)$}

Department of Applied Zoology, Kuvempu University,

Shankarghatta, Shimoga, Karnataka, India

e-mail: smajgi@indiatimes.com biological process (Pinel-Alloul 1995). The study of freshwater fauna especially zooplankton, even of a particular area is extensive and complicated due to environmental, physical, geographical and chemical variations involving ecological, extrinsic and intrinsic factors. Although the distribution of biodiversity across the earth can be described in terms of the relatively small number of spatial patterns such as latitude, altitude, or habitat size, understanding how these extrinsic drivers influence diversity remains one of the most significant intellectual challenges to ecologist and biogeographers (Gaston 2000). A large number of studies covering a wide variety of ecosystems and organisms, suggest that species richness tends to vary strongly with ecosystem production and habitat heterogenicity (Rosenzweig 1995). This is particularly so with freshwater fauna (zooplankton), which plays a key role in preservation and maintenance of ecological balance and its basic study is wanting and is absolutely necessary. The seasonal fluctuations of the zooplankton population are a well known phenomenon and zooplankton exhibits a bimodal oscillation with a spring and autumn in the temperate lakes and reservoirs Wetzel (2001). This fluctuation is greatly influenced by the variations in the temperature along with many other factors. Among several factors, temperature seems to exhibit the greatest influence on the periodicity of zooplanktons (Byars 1960; Battish and Kumari 1986; Prasad and Singh 2002). Water temperatures between $10-29^{\circ} \mathrm{C}$ are suitable for zooplankton development (Kaushik et al. 1992). However, in shallow tropical perennial or seasonal ponds such a regular food cycle can be seen. Thus, in any aquatic ecosystem zooplank- 
ton not only take part in transferring food from primary to secondary level but also switch over conversion of detritus matter into edible animal food.

With the passage of time, aquatic bodies in India and abroad became polluted gradually or abruptly due to human activities on land, in air or in water. The sewage, domestic wastes, industrial and agricultural effluents carrying organic matter to highly toxic substances reached the water and the situation became alarming. Consequently, the emphasis shifted to study the impact of pollutants on the zooplanktonic communities. There is no dearth of literature dealing with the various aspects of pollution and it is neither nor desirable to discuss all these finding here. Nevertheless, comparatively, recent references dealing with some aspects of pollution visà-vis zooplankton from water bodies from different parts of India will find mentioned in this paper.

\section{Material and methods}

The Karanja reservoir a major perennial reservoir of the district and located at Byalhalli village near Bidar district, which is $110 \mathrm{~km}$ away from the Gulbarga University campus which falls under $17^{\circ} 22^{\prime} 30^{\prime \prime} \mathrm{N}$ latitude and $76^{\circ} 59^{\prime} 0^{\prime \prime}$ E longitude (Fig. 1 and Plate I).
The catchment area of Karanja reservoir is 782.00 mile $^{2}\left(2,025.38 \mathrm{~km}^{2}\right)$ out of which 284.10 mile $^{2}$ $\left(727.29 \mathrm{~km}^{2}\right)$ i.e. $36.35 \%$ lies in Andhra Pradesh. The remaining $63.65 \%$ is in Karnataka. And live storage capacity is $7,316 \mathrm{mc}$. $\mathrm{ft}$ and dead storage capacity is $391.578 \mathrm{mc} \mathrm{ft}$. Capacity of the reservoir is $217.66 \mathrm{mc}$. The submergence area is 5,673 ha. This reservoir is exclusively used for irrigation and drinking purpose. This caters the needs of two taluks both Bhalki and Bidar.

The Bidar district falls under both the basins of Krishna and Godavari. The total area of district $5,448 \mathrm{~km}$. Out of which $85 \%$ lies in the Godavari basin and 15\% lies in Krishna basin. The maximum depth of the reservoir is $22.23 \mathrm{~m}$. The maximum height of the bund is $12 \mathrm{~m}$. The reservoir covered with full of aquatic vegetation, which increased protection of fish population and attraction to many birds. This reservoir extensively used for fishing since its inception.

Water samples collected for the purpose of estimation of various parameters were brought to the laboratory and subjected to analysis immediately as for as possible. Standards Methods for Estimation of Water and Wastewater 20th edition, 1998 were referred for estimation of parameters viz., Total Dissolved Solids, pH, Dissolved Oxygen, Free Carbondioxide, Total Alkalinity, Hardness, Calcium,

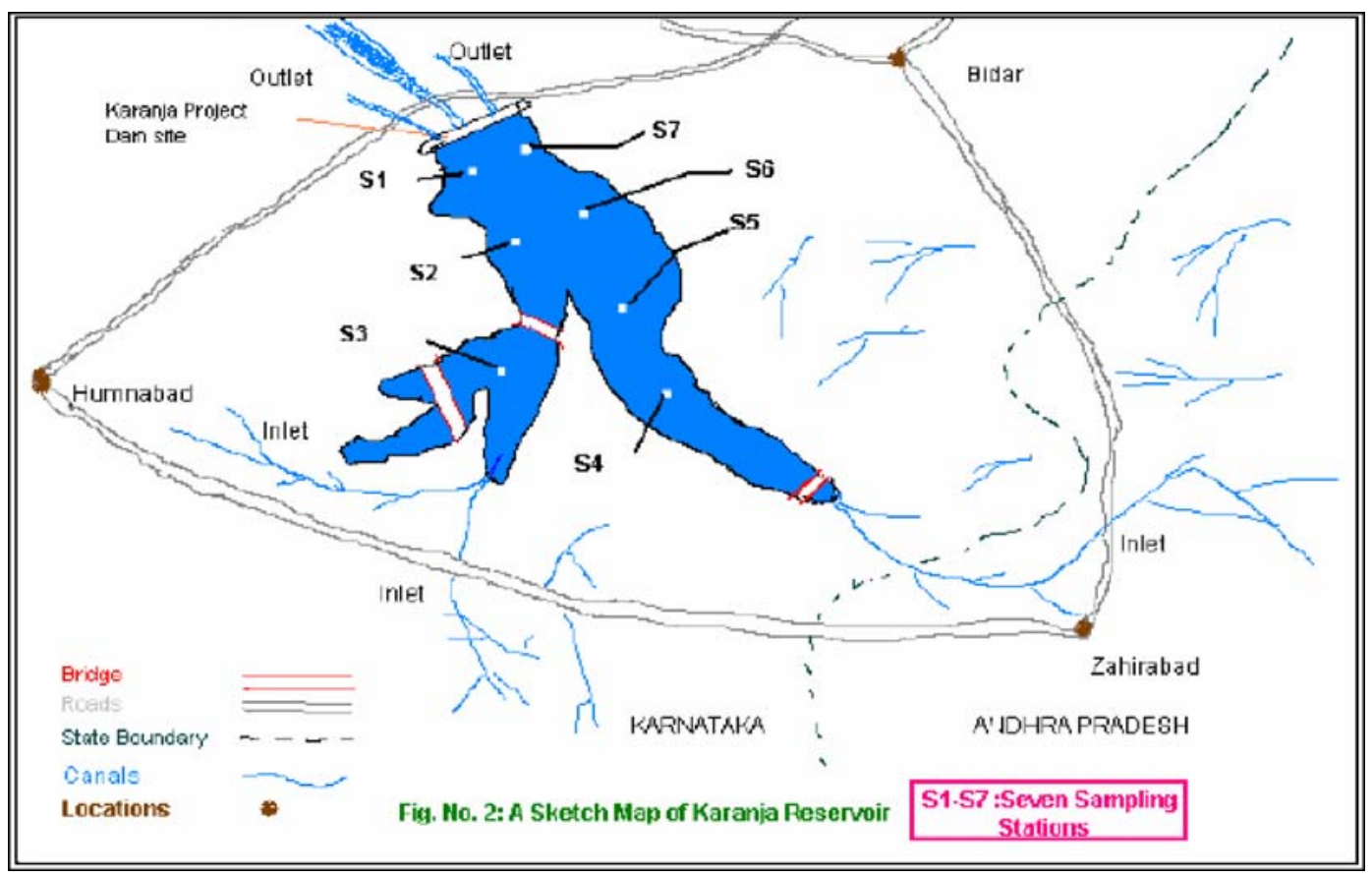

Fig. 1 Sketch map of the Karanja reservoir showing the different station 
Magnesium, Chloride, Ammonical Nitrogen, Phosphorus and Biochemical Oxygen Demand.

For qualitative and quantitative analysis of zooplankton, collections were made employing a modified Haron-Trantor net with a square metallic frame of $0.0625 \mathrm{~m}^{2}$ area. The filtering cone was made up of nylon bolting silk plankton net (No. 25 mesh size $50 \mu$ ) was used for collection of zooplankton. The net was hauled for a distance of $10 \mathrm{~m}$. Collected samples were transferred to labeled vial bottles containing 4\% formalin. The volume of filtered was calculated by multiplying the area of mouth of the net by the depth of the reservoir (i.e., the length through which the net was towed). After sedimentation $100 \mathrm{ml}$ of sample is subjected to centrifugation at 1,500 rpm for $20 \mathrm{~min}$ and used for further investigation. Counting the rotifera, cladocera, copepod and ostracoda was carried out using a Sedgewick Rafter cell. The data was used only to express the relative abundance of the principle zooplankton groups. (Needham and Needham 1962).

Zooplankton community diversity was analyzed for all four groups, species diversity $\left(\mathrm{H}^{*}\right)$ with log to base two was calculated using the Shannon Weiner index which has moderate sensitivity to the sample number (Magurran 1988). some values mentioned in No./lit. because only 1 month data cannot be computed for Shannon Weinner index.

\section{Shannon Weinner index}

$\mathrm{H}=\frac{\mathrm{S}}{\mathrm{I}=1}-\mathrm{SUM}(\mathrm{pi})(\log 2 \mathrm{pi})$

Where

H Shannon-Weiner diversity

SUM represents a capital epsilon

$\mathrm{s} \quad$ number of species

pi proportion of individuals of the total sample belonging to the ith species calculated as ni/ $\mathrm{N}$ for each ith species with ni being the number in species $\mathrm{i}$ and $\mathrm{N}$ the number of individuals in the sample.

\section{Results and discussions}

In Table 1 presented the values recorded for physicochemical variables in the samplings carried out in the study period. Temperature fluctuations in water was
Table 1 Average values of physico-chemical variables

\begin{tabular}{lccc}
\hline Parameters & NEM & Summer & SWM \\
\hline Atm. Temp. ${ }^{\circ} \mathrm{C}$ & 34.6 & 39.5 & 32.2 \\
Water Temp. ${ }^{\circ} \mathrm{C}$ & 29.1 & 33.2 & 28.2 \\
$\mathrm{pH}$ & 7.5 & 8.4 & 7.3 \\
TDS (mg/l) & 222.5 & 106 & 373.75 \\
DO (mg/l) & 5.9 & 8.05 & 5.8 \\
Total hardness (mg/l) & 141 & 65.3 & 125.5 \\
Chloride (mg/l) & 21.5 & 64.25 & 18.75 \\
\hline
\end{tabular}

influenced considerably by air temperature, humidity and solar radiation. The total dissolved solids were observed during SWM, while lower values were observed during NEM season. Highest concentration of total dissolved solids increases water turbidity, this in turn decreases the light penetration, thus affects the photosynthesis, thereby suppressing the primary producers in the form of algae and micophytes. The higher concentration of $\mathrm{pH}$ was observed during summer season could be attributed to enhanced rate of evaporation coupled with human interference are partly to enhanced photosynthetic activity. The higher values of dissolved were recorded during summer season, which may be due to increased solar radiation and thus, considerably good standing crop of phytoplankton productivity. The Karanja reservoir water is moderate hard water conditions, which in turn useful for the higher productivity. The chloride levels showed greater periodicity being higher during summer, which may be due to high rate of evaporation during hotter months.

The zooplankton of Karanja reservoir consists of Rotifers, Cladocera, Copepoda and Ostracods, the total 36 species were recorded from the Karanja reservoir during the present study. There was a distinct seasonal fluctuations and composition of the zooplankton in the Karanja reservoir with productive (October to May), retardation (June to August) and recovery (September onwards) periods. The total zooplankton population was dominated by rotifera (39\%), cladocera (33\%), copepoda (19\%) and ostracoda $(9 \%)$ respectively.

Among rotifera Keretella tropica, Brachionus falcatus, Brachionus calcifarus and Brachionus rubens were dominated in the present in the present investigate of rotifers. The monthly average is 25,719 and total number of individuals varied between 62 (August) to 2,073 (March) individual/lit. (Table 2). 
Table 2 Composition of zooplanktons

\begin{tabular}{|c|c|c|c|c|}
\hline \multirow[t]{2}{*}{ Months } & \multicolumn{4}{|c|}{ Planktonic groups } \\
\hline & Rotifera & Cladocera & Copepoda & Ostracoda \\
\hline Oct 2001 & 1,270 & 1,660 & 156 & 73 \\
\hline Nov & 1,560 & 1,728 & 200 & 196 \\
\hline Dec & 1,732 & 1,544 & 1,056 & 182 \\
\hline Jan 2002 & 1,972 & 1,478 & 943 & 432 \\
\hline Feb & 1,959 & 648 & 1,193 & 706 \\
\hline March & 1,907 & 379 & 1,468 & 588 \\
\hline April & 1,313 & 500 & 649 & 328 \\
\hline May & 506 & 298 & 616 & 262 \\
\hline June & 144 & 298 & 124 & 136 \\
\hline July & 137 & 902 & 130 & 84 \\
\hline August & 62 & 850 & 102 & 94 \\
\hline Sept & 164 & 896 & - & 78 \\
\hline Oct & 1,228 & 1,566 & 152 & 76 \\
\hline Nov & 1,383 & 1,718 & 232 & 202 \\
\hline Dec & 1,592 & 1,877 & 744 & 162 \\
\hline Jan 2003 & 2,106 & 1,497 & 912 & 337 \\
\hline Feb & 2,036 & 636 & 1,264 & 624 \\
\hline March & 2,073 & 454 & 1,499 & 810 \\
\hline April & 1,181 & 599 & 724 & 291 \\
\hline May & 702 & 362 & 710 & 280 \\
\hline June & 267 & 224 & 124 & 142 \\
\hline July & 176 & 650 & 136 & 96 \\
\hline August & 88 & 896 & 124 & 138 \\
\hline Sept & 161 & 992 & - & 142 \\
\hline Total & 25,719 & 22,652 & 13,257 & 6,459 \\
\hline
\end{tabular}

The composition of rotifera population showed higher population during NEM and summer, while, lower population observed in the month of August 2002 and same month of 2003. This may be due higher population of bacteria, organic matter of dead and decaying vegetation. The lowest population noticed in SWM season. This perhaps may be due to influence of copious quantity of rainwater and turbidity, which gets drained into the reservoir.

In the cladocera group Diaphanosoma sarsi, Diaphanosoma excisum, Macrothrix laticornis, Daphnia pulex and Diaphanosoma carinata were dominant in the present study. The monthly average number is 22,652 individual/lit. The no. of individual varied from 224 (January) to 1,877 (December) 2002. In 2 years observation cladocera population was maximum during NEM and SWM seasons, while during NEM season these population was minimum in the month of May of 2 years.
Among copepods Mesocyclops haylinus and Neodiaptomus strigilipes were dominant. Monthly average number of individuals/liter were 13,257 and number of individuals/liter varied between 102 (August) 2002 to 1,499 (March) 2003. During September of 2002 and 2003, copepoda species were absent. In the present study the population of this group exhibit distinct peaks during NEM season in particular in the month of December 2001 and January 2002. While, during February and March of 2002 and 2003 copepoda were lowest during SWM season.

Ostracoda occupied fourth position of zooplankton and represented very low population diversity compared to other groups. Three species were identified Hemicypris fossulate, Spirocypris and Hyocypris. During NEM season lowest population was observed. H. fossulate was not observed in December, the Spirocypris during October and November. Higher population was observed during summer of both years.

However, during SWM season ostracods population is recorded lower side when compared to NEM season. The average is 6459 individuals/liter and average number of individuals varied between 73 (October) 2001 to 810 (March) 2003.

The densities of various zooplankton thus, in the order rotifera $>$ cladocera $>$ copepoda $>$ ostracoda. In the present study zooplankton communities have shown the positive correlation with $\mathrm{pH}$, dissolved oxygen, total alkalinity, chloride, gross primary productivity, and net primary productivity. Hierarchial cluster analysis revealed three clusters. Clusters above $80 \%$ to $95 \%$ are considered. Eighty percent clusters has two groups copepoda and ostracoda. Ninety-five percent cluster is having rotifera and clodocera. These groups are indirectly controlled by rotifera and copepoda belonging to $0 \%$ cluster (Dendrogram Fig. 1).

\section{Diversity studies}

The Shannan Weiner diversity indices of the rotifers were observed highest 3.1659 in the March and lowest 1.332 in August during 2001 and 2002 where as in 2002 and 2003 highest 3.0544 in February and where as lowest 1.4105 in August (Table 3). For Cladocera shown 2.3324 peaks in the month of December and lowest 0.5120 in June. Similarly in 2001 and 2002 highest diversity observed 2.6081 in December and 0.6661 lowest in February (Table 4). 2.2764 is the highest value 


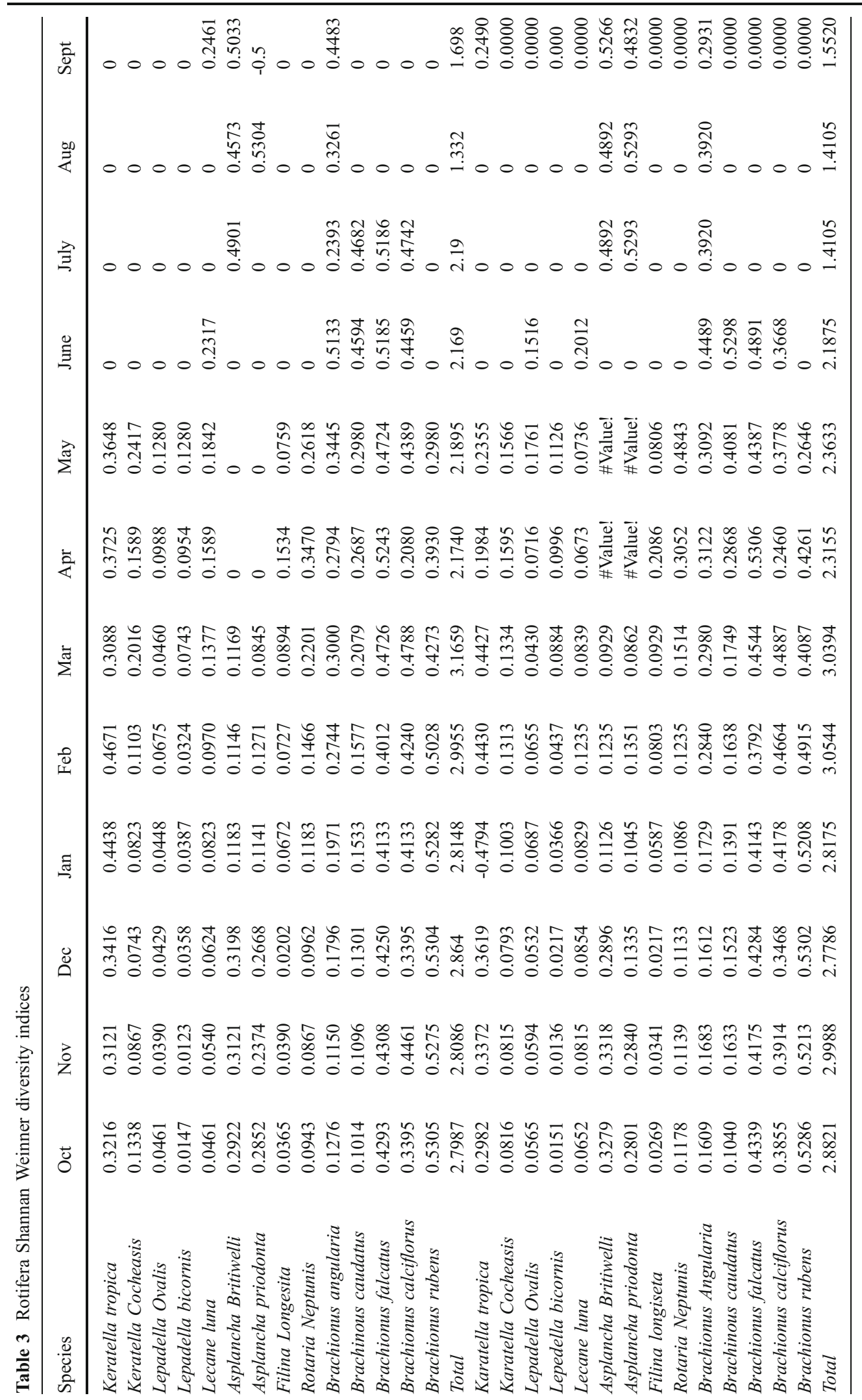


Table 4 Cladocera Shannan Wannon diversity indices

\begin{tabular}{|c|c|c|c|c|c|c|c|c|c|c|c|c|}
\hline Species & Oct & Nov & Dec & Jan & Feb & Mar & Apr & May & Jun & Jul & Aug & Sept \\
\hline Moina brachiata & 0.2624 & 0.2379 & 0.1365 & 0.1699 & 0.3239 & 0 & 0 & 0 & 0.5307 & 0.4659 & 0 & 0 \\
\hline Moina macrocopa & 0 & 0 & 0 & 0.0408 & 0 & 0 & 0 & 0 & 0 & 0 & 0.2144 & 0.2666 \\
\hline Moina rectirostris & 0 & 0 & 0.1648 & 0.0774 & 0 & 0 & 0 & 0 & 0.3889 & 0.2546 & 0.2915 & 0.3019 \\
\hline Daphnia pulex & 0.4877 & 0.4932 & 0.5286 & 0.5272 & 0.4308 & 0.5264 & 0.5222 & 0 & 0 & 0 & 0 & 0 \\
\hline Daphnia carinata & 0.4818 & 0.5049 & 0.5141 & 0.5260 & 0.4983 & 0.5173 & 0.4276 & 0.1717 & 0 & 0 & 0 & 0 \\
\hline Macrothrix laticornis & 0.5180 & 0.5000 & 0.3988 & 0.3699 & 0.4799 & 0.4737 & 0.2538 & 0.3206 & 0 & & 0 & 0 \\
\hline Euryalona orientalis & 0.0371 & 0.0498 & 0.0683 & 0.0323 & 0 & 0 & 0 & 0 & 0 & & 0.0634 & 0.0724 \\
\hline Latonopsis australis & 0.0117 & 0.0113 & 0.0311 & 0.0323 & 0 & 0 & 0 & 0 & 0.1401 & 0.0720 & 0.0868 & 0.0608 \\
\hline Alona pulchella & 0.0293 & 0.0359 & 0.0311 & 0.0323 & 0.0453 & 0.0824 & 0.0766 & 0.1643 & 0 & & 0 & 0 \\
\hline Diaphanosoma sarsi & 0.3253 & 0.3202 & 0.3006 & 0.1877 & 0.3867 & 0 & 0 & 0 & 0 & 0.4954 & 0.4422 & 0.4062 \\
\hline Diaphanosoma excisum & 0.3009 & 0.3085 & 0.2950 & 0.1460 & 0.3867 & 0 & 0 & 0 & 0.5120 & 0.4751 & 0.4983 & 0.4438 \\
\hline Total & 2.1919 & 2.2237 & 2.3324 & 2.1416 & 0.8187 & 1.5997 & 1.2802 & 0.6566 & 0.5120 & 0.9705 & 0.9405 & 1.5517 \\
\hline VMoina brachiata & 0 & 0 & 0.3050 & 0.2995 & 0.3762 & 0.3581 & 0 & 0 & 0 & 0 & 0.0608 & 0.0770 \\
\hline Moina macrocopa & 0.0741 & 0.1527 & 0.1625 & 0.1544 & 0 & 0.0000 & 0 & 0 & 0 & 0.3768 & 0.3750 & 0.4197 \\
\hline Moina rectirostris & 0.0466 & 0 & 0.1393 & 0.1074 & 0 & 0.0000 & 0 & 0 & 0.4342 & 0.2475 & 0.2666 & 0.3058 \\
\hline Daphnia pulex & 0.5029 & 0.5205 & 0.5270 & 0.5244 & 0.4570 & 0.5234 & 0.5144 & 0.3512 & 0 & 0 & 0.0000 & 0.0000 \\
\hline Daphnia carinata & 0.4637 & 0.5090 & 0.4978 & 0.5295 & 0.4935 & 0.5307 & 0.4165 & 0.3099 & 0 & 0 & 0.0000 & 0.0000 \\
\hline Macrothrix laticornis & 0.5062 & 0.4995 & 0.4228 & 0.3472 & 0.4973 & 0.4667 & 0.2728 & 0.3512 & 0 & 0 & 0.0000 & 0.0000 \\
\hline Euryalona orientalis & 0.0539 & 0.0565 & 0.0369 & 0.0128 & 0 & 0.0000 & 0 & 0 & 0 & 0 & 0.0000 & 0.0000 \\
\hline Latonopsis australis & 0.0123 & 0.0204 & 0.0336 & 0.0403 & 0 & 0.0000 & 0 & 0 & 0.0608 & 0.0624 & 0.0608 & 0.0181 \\
\hline Alona pulchella & 0.0220 & 0.0285 & 0.0265 & 0.0319 & 0.0261 & 0.0345 & 0.0832 & 0.1430 & 0 & 0 & 0.0000 & 0.0000 \\
\hline Diaphanosoma sarsi & 0.4301 & 0.2095 & 0.1873 & 0.1544 & 0.2589 & 0.0000 & 0 & 0 & 0.4011 & 0.4721 & 0.4556 & 0.4632 \\
\hline Diaphanosoma excisum & 0.3088 & 0.3189 & 0.2693 & 0.1860 & 0.3810 & 0.0000 & 0 & 0 & 0.3796 & 0.4996 & 0.4709 & 0.4383 \\
\hline Total & 2.4205 & 2.1629 & 2.6081 & 2.3178 & 0.6661 & 1.9133 & 1.28687 & 1.1552 & 1.2756 & 1.6584 & 1.6896 & 1.7221 \\
\hline
\end{tabular}

and 0.2387 is the lowest for Copepoda during 2001 and 2002 where as in 2002 and 2003 highest value is 2.0396 and lowest is 1.0941 in July and no diversity found in September and only one species found in August (Table 5). Therefore for one species diversity values cannot be presented. Similarly for Ostracoda highest values 1.4900 and 1.4505 obtained in January and August where as, lowest values obtained in September and December only one species obtained during 20012002 and 2002-2003 respectively (Table 6).

Table 5 Copepoda

\begin{tabular}{llllllllllllll}
\hline Species & Oct & Nov & Dec & Jan & Feb & Mar & Apr & May & Jun & Jul & Aug & Sept \\
\hline Mesocyclops leuckarti & 0.0000 & 0.0000 & 0.3028 & 0.3785 & 0.2437 & 0.1614 & 0.2141 & 0.0000 & 0.1605 & 0.5232 & 0 & - \\
Mesocyclops hyalinus & 0.0000 & 0.0000 & 0.4989 & 0.4434 & 0.5094 & 0.5306 & 0.4660 & 0.3824 & 0.5127 & 0 & 0 & - \\
Paracyclops fimbriatus & 0.5302 & 0.5305 & 0.3597 & 0.4085 & 0.1232 & 0.1147 & 0.1655 & 0.1107 & 0.0000 & 0 & 0 & - \\
Heliodiaptomus viduus & 0.2198 & 0.2161 & 0.0171 & 0.0264 & 0.3618 & 0.3509 & 0.4863 & 0.4985 & 0.0000 & 0.0926 & 0 \\
Rhinediaptomus indicus & 0.0806 & 0.0664 & 0.0305 & 0.0188 & 0.0576 & 0.0410 & 0.0928 & 0.0814 & 0.0960 & 0.0926 & 0.1832 & - \\
Tropocyclops prasinus & 0.4736 & 0.4684 & 0.4125 & 0.4728 & 0.2162 & 0.2053 & 0.3995 & 0.3510 & 0.0960 & 0.3943 & 0.0000 & - \\
Neodiaptomus strigilipes & 0.0000 & 0.0000 & 0.5294 & 0.5280 & 0.5106 & 0.5276 & 0.5278 & 0.4567 & 0.5000 & 1.1028 & 0.0555 & - \\
Total & 1.3042 & 1.2814 & 2.1510 & 2.2764 & 2.0225 & 1.9314 & 2.3520 & 2.0413 & 1.2048 & 0.5232 & 0.2387 & - \\
Mesocyclops leuckarti & 0.0000 & 0.0000 & 0.3459 & 0.3645 & 0.2268 & 0.1185 & 0.1724 & 0.1536 & 0.0000 & 0.0000 & - \\
Mesocyclops hyalinus & 0.0000 & 0.0000 & 0.0000 & 0.4178 & 0.5161 & 0.5307 & 0.4233 & 0.3703 & 0.5290 & 0.5140 & - \\
Paracyclops fimbriatus & 0.5294 & 0.5307 & 0.4535 & 0.1696 & 0.2087 & 0.1292 & 0.0718 & 0.0841 & 0.0000 & 0.0000 & - \\
Heliodiaptomus viduus & 0.1841 & 0.1675 & 0.0561 & 0.0599 & 0.3098 & 0.3767 & 0.4771 & 0.3771 & 0.0000 & 0.0000 & - \\
Rhinediaptomus indicus & 0.0822 & 0.0591 & 0.0405 & 0.0194 & 0.0462 & 0.0482 & 0.0718 & 0.0000 & 0.0000 & 0.0000 & - \\
Tropocyclops prasinus & 0.4384 & 0.4517 & 0.5070 & 0.4893 & 0.1792 & 0.1901 & 0.4130 & 0.4138 & 0.2114 & 0.1986 \\
Neodiaptomus strigilipes & 0.0000 & 0.0000 & 0.5241 & 0.5192 & 0.5079 & 0.5266 & 0.5267 & 0.4373 & 0.4329 & 0.3815 & 134 \\
Total & 1.2341 & 1.2090 & 1.9271 & 2.0396 & 1.9947 & 1.9200 & 2.1561 & 1.8663 & 1.1733 & 1.0941 & - \\
\hline
\end{tabular}


Table 6 Ostracoda

\begin{tabular}{lllllllllllllll}
\hline Species & Oct & Nov & Dec & Jan & Feb & Mar & Apr & May & Jun & Jul & Aug & Sept \\
\hline Hemicypris fossulate & 0.3977 & 0.4490 & 0 & 0.5025 & 0.3784 & 0.4308 & 0.4972 & 0.4983 & 0.4503 & 0.5305 & 0.4594 & \\
Spirocypris & 0.0000 & \#VALUE! & 0.4804 & 0.4917 & 0.5235 & 0.5307 & 0.5121 & 0.5135 & 0.5271 & 0.4098 & 0.5245 & \\
Hyocypris sp. & 0.5294 & 0.2390 & 0.2794 & 0.4958 & 0.0732 & 0.1000 & 0.1307 & 0.1537 & 0.0000 & 0.0000 & 0.0000 & 78 & 0.975 \\
Total & 0.9272 & 0.2390 & 0.7598 & 1.4900 & 0.9752 & 1.0615 & 1.1400 & 1.1654 & 0.9774 & 0.9403 & 0.9839 & 78 \\
Hemicypris fossulate & 0.5106 & 0.4086 & & 0 & 0.4213 & 0.5037 & 0.5227 & 0.5239 & 0.5252 & 0.5185 & 0.5280 & 0.4057 \\
Spirocypris & 0.0000 & 0.0000 & & 0.5073 & 0.5303 & 0.5027 & 0.4016 & 0.5000 & 0.4575 & 0.3524 & 0.5186 & 0.5149 \\
Hyocypris sp. & 0.4874 & 0.1975 & 162 & 0.3256 & 0.1096 & 0.0900 & 0.1897 & 0.2720 & 0.0000 & 0.0000 & 0.4039 & 0.2696 \\
Total & 0.9980 & 0.6061 & 162 & 0.8329 & 1.0612 & 1.0964 & 1.1140 & 1.2958 & 0.9826 & 0.8709 & 1.4505 & 0.4057 \\
\hline
\end{tabular}

The results indicates that the maximum number of genera occurred during winter season than summer and monsoon season which also reported by Abdus et al (1995), Kumar (2001). The less number of genera might be attributed to the less nutrients in the reservoir which consequently result in less productivity or might be due to the depletion of important factors such as dissolved oxygen and $\mathrm{pH}$ (Fig. 2).

The reduction in the number of genera (species) may be due to predation, variation in the $\mathrm{pH}$ of water is always associated with the genera (species) composition of Zooplankton inhibiting among them (Jhingran 1982). In winter, it is biotic interaction operating through feeding pressure rather than water quality it seems to affect the zooplankton diversity and density particularly the stocked fish species play an important role in harvesting species of copepoda and cladocera, thereby reducing their predatory pressure on other groups. The rotifers and particle feeder cladocera were higher in winter can be linked to favorable temperature and availability of abundant food in the form of bacteria, nanoplankton and suspended detritus (Edmondson, 1965; Baker, 1979).
Open Access This article is distributed under the terms of the Creative Commons Attribution Noncommercial License which permits any noncommercial use, distribution, and reproduction in any medium, provided the original author(s) and source are credited.

\section{Appendix}

Referees

1. Dr. R. Ramanibai, Professor, Dept. of Zoology, Guindy Campus, Chennai-600 025.

Tamil Nadu, India

Email: rrmani8@hotmail.com

(R) 044-22351367

(0) $044-24475654$

2. Dr. Nagaraj rao

Professor

Dept. of Zoology,

Koti Women's College
Fig. 2 Hierarchical cluster analysis of Zooplankton communities

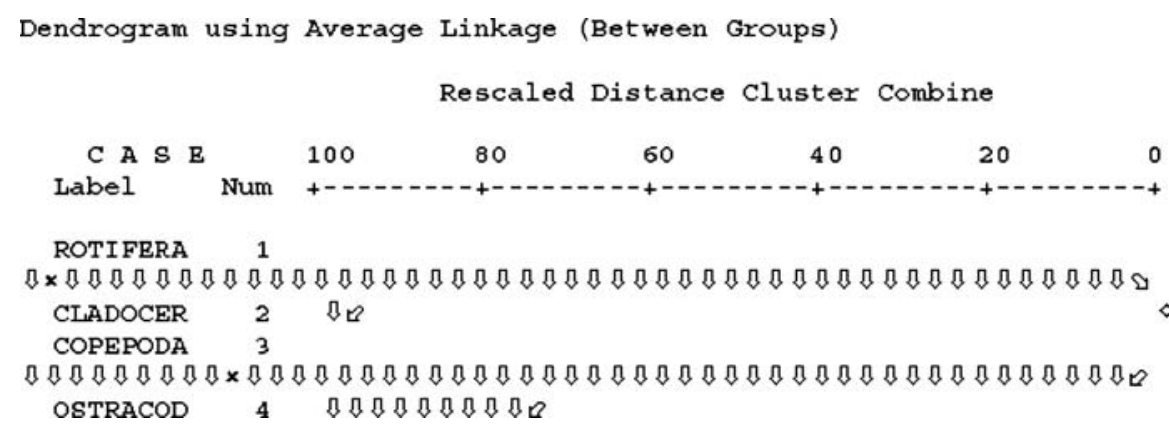


Osmania University,

Hyderabad-500095

Andhra Pradesh, India

Email: nagarajaraop@yahoo.com

3. Dr. Sammaiah,

Professor,

Dept. of Zoology,

Kakatiya University,

Warangal-560 009,

Andhra Pradesh, India

Email: sammaiah_ch@yahoo.com

Mobile: 09849870560

4. Dr. D. V. Muley,

Reader,

Dept. of Zoology,

Shivaji University,

Kolhapur-416 004.

Maharashtra, India

drdvmuley@yahoo.com

(R) 0231-2607122

\section{References}

Abdus, Saboor., \& Altaff, K. (1995). Qualitative and Quantitative analysis of zooplankton population of tropical pond during summer and rainy season. J Eco Biol, 7(4), 269-275.

Baker, R. L. (1979). Specific status of Keretella cochearis (Gosse) and K. earliner, Ahlstrom (Rotifera: Brachionidae)
Morphological and ecological considerations. Con J. Zool, 57(9), 1719-1722.

Battish, S. K., \& Kumari, P. (1986). Effect of physico-chemical factors on the seasonal abundance of cladocera in typical pond at village of Raqba, Ludhiana. Ecology, 13(1), 146-151.

Byars, J. A. (1960). A freshwater pond in New Zealand. Australian Journal of Marine and Freshwater Research, 11, 222-240.

Edmondson, W. T. (1965). Reproductive rate of planktonic rotifers as related to food and temperature. Ecol. Manoir, $35,61-111$.

Gaston, K. J. (2000). Global patterns in biodiversity. Nature, $405,220-227$.

Jhingran, V. G. (1982). Fish and fisheries of India, (pp. 268269). New Delhi: Hindustan.

Kaushik, S., Agarkar, M. S., \& Saxena, D. N. (1992). Distribution of phytoplankton in riverine waters in Chambal area, Madhya Pradesh. Bionature, 12, 1-7.

Kumar, K. S. (2001). Studies on the freshwater copepods and cladocerans of Dharmapuri Dist. Tamil Nadu. J. Aqua. Biol, 16(1\&2), 5-10.

Magurran, A. E. (1988). Ecologogical diversity and its measurement, (p. 197). New Jersey: Princeton University Press.

Needham, J. G., \& Needham, P. R. (1962). A guide to the study of freshwater biology, (p. 108). San Francisco: Holden day Ins.

Prasad, B. B., \& Singh, R. B. (2003). Composition, abundance and distribution of phytoplankton and zoobenthos in a tropical water body. Nat. Environ. \& Poll. Tech, 2(3), 255-258.

Pinel-Alloul, B. (1995). Spatial hetrogenisity is a multiscale characteristic of zooplankton community. Hydrobiologia, 301, 17-42.

Rosenzweig, M. L. (1995). Species diversity in space and time. Cambridge: Cambridge University Press.

Wetzel, R. G. (2001). Limnology; Lakes and reservoir ecosystem (p. 1006, 3rd edn.). Burlington: Academic. 